\title{
CULTURE (YORÙBÁ) AS A MEANS OF DE-ESCALATING CONFLICT AND MAINTAINING PEACE
}

\author{
Akintayo Sunday Olayinka ${ }^{1}$ \\ ${ }^{1}$ Affiliation not available
}

March 12, 2021

\begin{abstract}
Most works in peace studies concern interventions in conflict situations - such as conflict management - or projects seeking to sustain peace after a conflict, such as conflict resolution and peace education. However, using a peace lens, this study affirms culture as one of the means the Yorùbá utilize to sustain peace in their community. The paper ascertains the presence of conflict and proceed to discuss how some features of Yorùbá culture facilitate harmony. This article is based on a primary research among the Yorùbá within 2014 and 2020, the bulk of which is taken from chapter 5 of the dissertation.
\end{abstract}

\section{Introduction}

Culture has been studied in sociology, history, cultural studies, and anthropology over the years. While Bauman (1999) discusses culture as concept, structure and praxis, Susman (2012) discusses culture as history. According to Arnold, 'Culture [...] has one great passion, the passion for sweetness and light.' (1869, p. 7). Put in another way, Sewell Jr., describes culture as providing meaning for life '[...] the sphere devoted specially to the production, circulation, and use of meanings.' $(2005$, p. 80$)$. To Schein, it has to do with long lived experience for problem solving, (2012, p. 314). Williams suggests culture has to do with universal values, intellectual and a particular way of life, (2006, p. 32). Bagby included race, hereditary, physical and physiological, plants within an appropriate geographical location as contributing to the cause and culture of a people, which also constitutes the regularities found among them, (1953, pp. 546, 547). To this, Bagby adds, 'The shape and structure of the human foot serves to limit the possible forms of foot-gear [... ]' (1953, p. 546). Meaning the anatomy of the foot determines the shoe type, which also connects with the arts or preferred shoes and social behaviour like a dance. So, the needs determine the wear, clothing and other arts that make up a culture, while the available plants dictate the local people's choice of food, essential jobs, and social interaction. Most people living in riverine areas do sea related jobs, like fishing among the Ogoni in Nigeria, which also shape their culture. This implies that culture as to do with several aspect of human's life, needs and make up. How then does culture speak for peace in human society?

Scholars like Kyrou have examined what it takes to go beyond environmental problems into 'the inherent capacities of the environment to inform and sustain peace' described as 'environmental peacemaking' or 'peace ecology' (2007, p. 73). Like Kyrou, this study projects the capacity of a community to sustain its peace in the cultural and religious domains. Anthropology has continued to examine the peaceful societies 'PS' (Peaceful-Societies, 2019) that is, some selected tribes and communities who use their potentials to dissociate themselves from violence and resolve their conflict as much as possible. Who are the PS and what features do they possess that facilitate their peacefulness? In the rest of this paper, the author shall provide 
the statement of the problem, methodology, a brief description of the Peaceful Societies (PS) and his findings about the cause of peace among the southwest Nigerian Yorùbá.

\section{A. Statement of the Problem and Methodology}

It has been suggested that religious violence is less pronounced in southwest Nigeria especially between Christian and Muslims when compared with the northern states with reference to the Yorùbá tolerance and culture (Bolaji, 2013; Lateju, 2012; Osaghae \& Suberu, 2005; Parrinder, 1959; Peel, 2016; Ukiwo, 2003). The aspect of the culture that informs peacefulness requires further investigation. This study, therefore, employs empirical methods to examine the situation among the Yorùbá on religious and cultural grounds, the political and economic violence that cut across the entire Nigeria as a country notwithstanding.

This study employed a survey, focus groups (FG) and interviews among the southwest Nigerian Yorùbá to generate its data. The data analysis was done with Nvivo pro 12 to generate various nodes and themes for the peacefulness among the Yorùbá, while thick description was used to develop the themes. This is

a primary research on how the Yorùbá manage their disputes and conflicts whilst sustaining its peace, a hopeful example of peaceful society (PS) in West Africa.

\section{B. Peaceful Societies}

Many societies (communities of people) have been identified as being peaceful across the globe based on the assessments of some anthropologists (Fry, 2007). 25 of the societies are discussed on the peaceful societies' webpage of the Department of Anthropology, University of Alabama, United States of America. Among the list are the Nubians, Amish, Semai, Batek, Birhor, Hutterites, Ju/'hoansi, Ladakhi, Lepchas, Malapandaram, Mbuti, Paliyans.[1] Bonta identifies 40 of them (1996), while Melko et al. (1983) identified 52 (Melko, 1972); the differences in the figures based on the dates covered in the study. Similarly, dates and updates are important as a community that used to be peaceful might have fallen from such status due to some circumstances surrounding them like wars and would require a new assessment for peacefulness. Melko et al. (1983) mentions a hundred years as required for a review after a community or nation has departed from their peaceful status to assess if they could be reconsidered as being peaceful again.

A close study of the current peaceful societies as also enlisted by the Department of Anthropology, University of Alabama, United States of America, shows that many of them are farmers, fruit -gatherers, fishermen and hunters, sometimes migrating within the forests while some have settled to cultivate farms (Draper, 1975; Howell, 1989; Lutz, 1990; Saraswati, 1995; Thomas, 1989). A few of them are open to modern education but often return to their settlement to practise their valued culture (Gardner, 2000; Howell, 1989). Some of them, like Ju'hoansi or Bushmen wear minimal clothing, (Thomas, 1989), while some others cherish attire they have for social contact (Briggs, 1970). The studies cover North and South America, Canada, Asia, Europe, and North and East/Central Africa. Yet, there are no examples of peaceful societies from West Africa on the list.

It has been observed that these societies often avoid anger, greed, and ostracize any deviants from their communities to retain their peacefulness (Briggs, 1994; Briggs, 1970; Fry, 2007). They recognize greed as among the causes of rivalry that lead to resentment and violence and some have a hierarchy of leadership to disseminate information, wisdom and resolve conflicts (Fry, 2007).

Although some of the groups or colonies sometimes show a level of deviant behaviour like homicide (Briggs, 1994; Peaceful-Societies, 2019), they feel disappointed about such and seek to project their strategies to further enhance harmony, tolerance, devalue competition and disputes from leading to further violence (Howell, 1989). Some themes come out clearly under peaceful societies (PS) like the make of peaceful components of a society, leadership and social relations, childhood informal education, control or management of aggression, and the fear of strangers (outsiders). Melko discusses the vital roles the PS leadership (or government) play in maintaining peace in their societies, (1972). Melke describes the features their governments use as: 
Workable distribution of power, establishing one of two religious policies (sic), and form some sort of flexible, permanent government... peace can be maintained for many decades despite (or possibly because) of mediocre leadership. (Melke, 1972, p. 1)

The PS may not be offended by Melke's use of mediocre here, if their goals to keep the peace and have their children living are safety is met.

What are the mechanisms of peacefulness? Considering examples of peacefulness, the Semai are well recognized as peaceful people who are not known for physical violence, fighting, or beating their spouses (Robarchek \& Robarchek, 1998). When recruited by the British army in a fight against the communist insurgency, the Semai still returned to their peacefulness after the war (Peaceful-Societies, 2019). They cherish their culture, like the people of Tristan da Cunha, when initially displaced due to volcanic eruption in 1961 demanded to return to their island later, showing their commitment to their non-violence and self-assertion, (Munch, 1964). Willis' study of the Ufipa (Fipa) southwest of Tanzania shows that the Ufipa people were known to be peaceful (even as early as 1880). They became aggressive because of wars at some point preceding the arrival of the Europeans but returned to the peacefulness they had been known for later (Willis, 1989). Their worldview of what it takes to be human is relevant to their return to peacefulness. The Ufipa, Batek and !Kung treat their men and women equally compared to male leadership or hierarchy in some other places, (Endicott, 1981; Willis, 1989). Many !Kung women exercise some freedom by working, distinguishing edible food from other desert produces, while the Batek husband and wife make joint decisions whereas in some others, the structure makes male authority dominant, (Endicott, 1981). Similarly, although the Chewong recognize their boys and girls as being different physiologically, they treat their young equally with no valuerelated prejudices, (Howell, 1989). Also, according to Lutz, the Ifaluk have learnt to control their anger but permit righteous indignation for correcting an erring member as justifiable, yet without violence, (Lutz, 1990). As among the Paliyan foragers, Gardner writes, 'Paliyans have a system of institutions that bear upon the avoiding of violence. In the forest and now in settled villages, too, they are able to remain relatively nonviolent,' (Gardner, 2000, p. 232). What constitutes peacefulness among these societies, therefore, ranges from the management of their innate ideas to the valued and promoted culture of the people concerned.

What correlations can one obtain between the PS and a community within a developing nation like the Nigerian Yorùbá in this study? In as much as various conflict theories like conflict resolution and transformation have caught the attention of many peace scholars and practitioners, more recent works in anthropology like PS are also ongoing underscoring how communities keep their peace. An inquiry into more communities to explore their potential for peacefulness to contribute to peace and conflict studies is worth doing. This is to verify what variants of peace can be found in such communities and how they de-escalate tension, as a guide to reducing conflict occurrences in human societies.

The PS in this category have their peculiar problems just as the Yorùbá also have theirs. Some associated problems with PS are poverty and the lack of connection with the outside world, yet there are areas of strength like a loose leadership hierarchy, a productive social set-up and a communal lifestyle that discourages greed as mentioned earlier. These societies do not sometimes see the acclaimed weakness as a problem, but non-native scholars often do. How much of these correlates to or diverge from the Yorùbá acclaimed peacefulness?

\section{Conflict De-Escalation and Peace Maintenance Features Among the Yorùbá}

In this study, the author asked the participants, among other questions, to provide or discuss the reasons behind the less interreligious violence among the southwest Nigeria Yorùbá. The in-depth study of the data generated from this study led to the relevant themes discussed in this paper. The cumulative nodes/sunburst chart from the findings reveals six themes, namely:

1. Yorùbá culture 
2. Family

3. Social interactions

4. Community life

5. The way in which the subjects practise their religions.

6. The multi-faceted nature of occasional conflicts among the Yorùbá

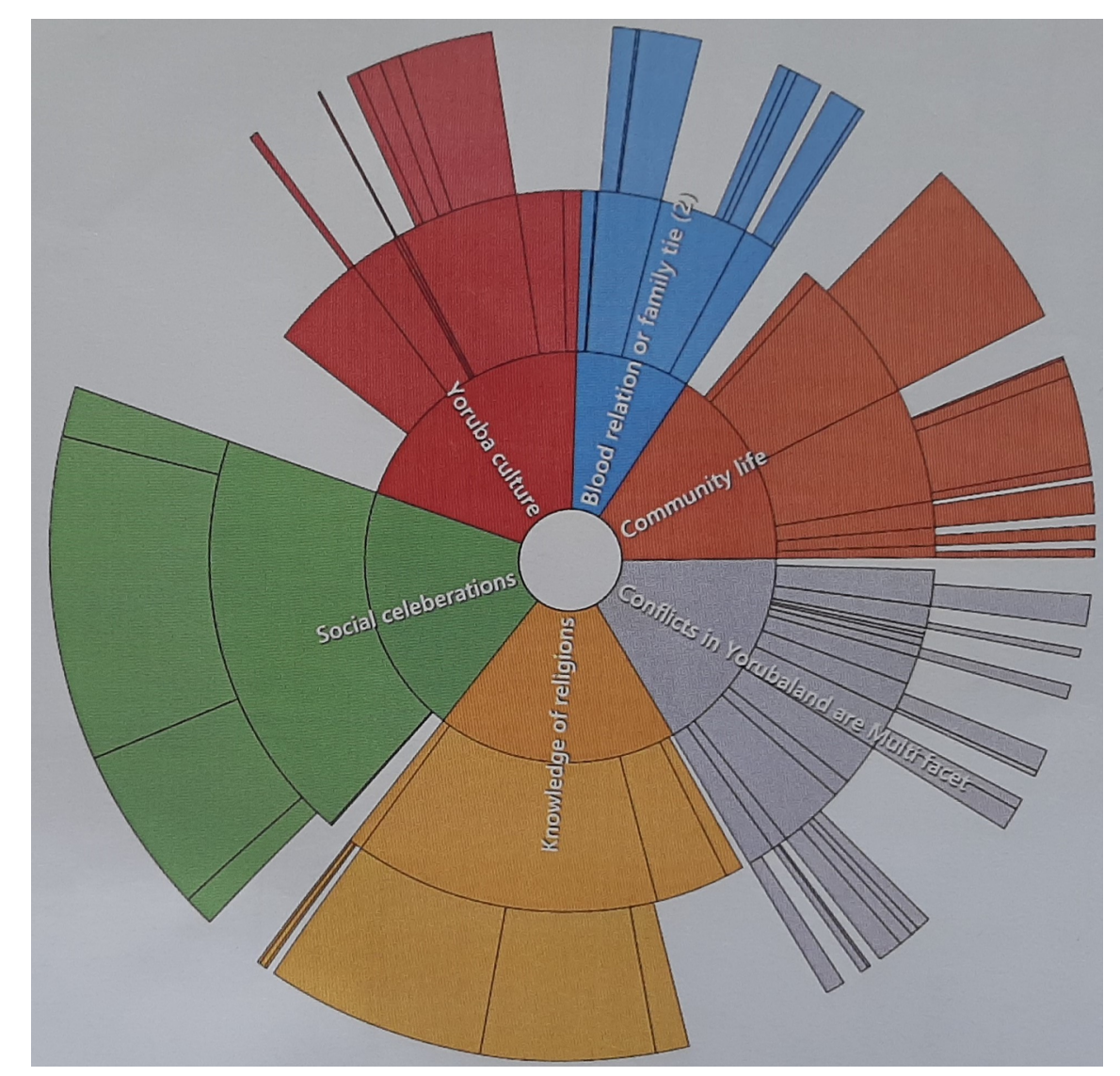

Figure 1: NVivo Cumulative Nodes/Sunburst

However, the NVivo Cumulative Hierarchy chart from the same study provides further details of the contents of each of the six themes which are lacking in the previous scholar's works on the subject. Previous studies mentioned culture and religious tolerance (Lateju, 2012) while this provides what constitutes the culture and tolerance in context from an empirical study. 


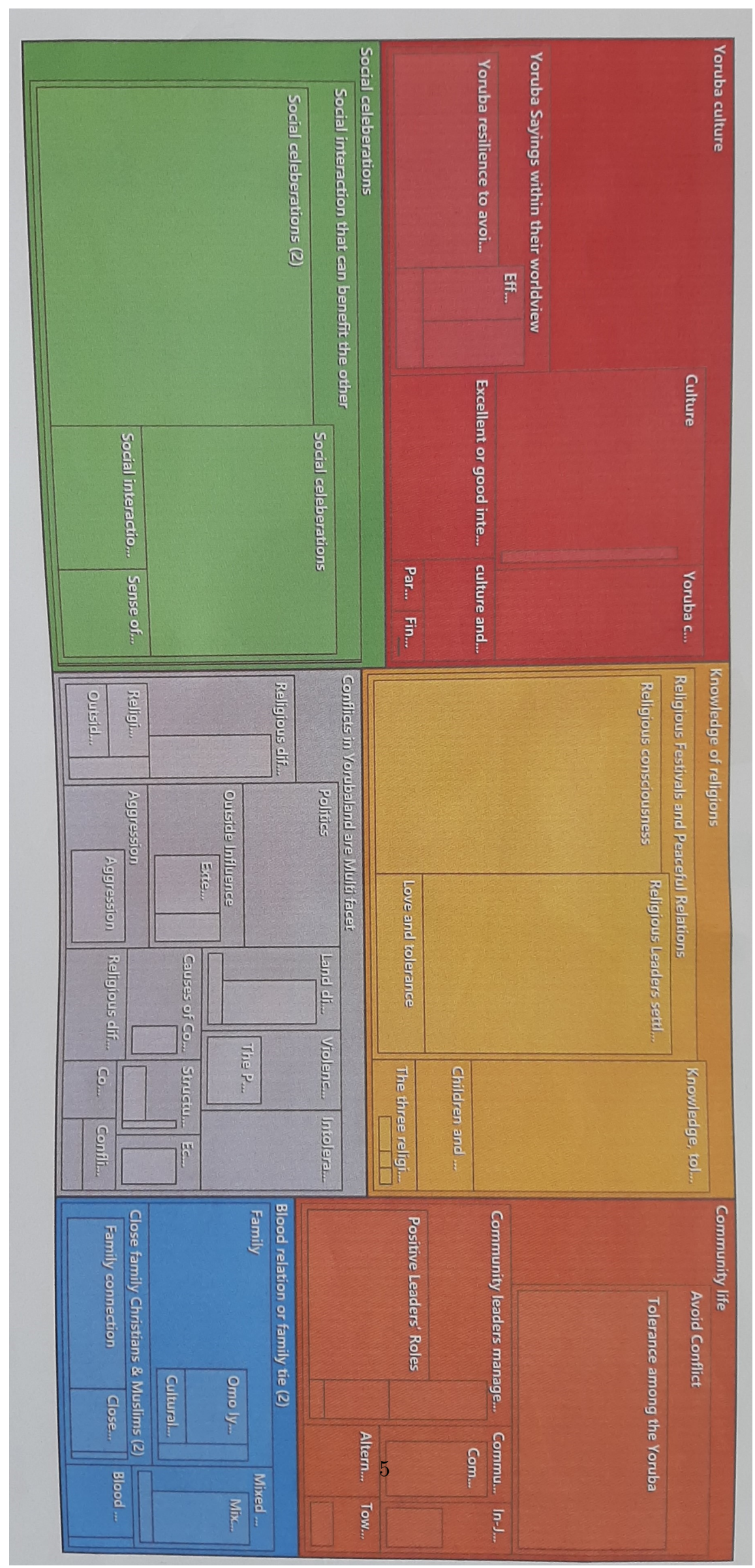

Figure 2: NVivo Cumulative Hierarchy chart 
The first five themes suggest what constitute the features that help the Yorùbá sustain their peace and to live in harmony, while they are faced with the sixth theme to work on whenever it appears. This suggests that what constitutes the Yorùbá culture along with some specific related themes like family, social interaction and community life were the cause of their peacefulness. Thus, a failure to handle the occasional conflicts mentioned in the sixth theme leads to violence, unless or until their leaders are proactive on each occasion to manage it to keep it brief. For the Yorùbá, the culture, social interactions, community life, family, and religious cooperation or understanding are the suggested useful ways of de-escalating disputes and conflicts to retain peace. Following are the elaborations of the findings.

\section{A. Violent Conflict among the Yorùbá}

This research shows that, like any human community, the PS included, the Yorùbá experience conflicts of different sorts. This is not to diminish the strength they have displayed in seeking to maintain their harmony, especially in the religious and cultural spheres. Yet, it is worth mentioning some of the conflicts that they have experienced over the years.

Land disputes are one of the main causes of conflict among the Yorùbá. Both Wlé and Ifá in the focus group (FGD3) discussed some of the violent conflicts that have occurred among the Yorùbá such as the town conflicts of Ile-Ife versus Modákke, the ffa versus rinle and the Saragi versus Odò wá. The ffa- rinle led to calls for divorce where their children had inter-married. Calls for divorce also arose among the Ile-If and Modákke people, as Wlé reiterates. In a separate interview, mb (FI) mentions the various conflicts and wars among the Yorùbá in relation to land disputes, such as the Karigi and Ibadan, the Ogunmla and Shodk, Ikirun and baagùn boundary disputes, and the Modákke and Ile-If conflicts. According to mb, the Ife and Modákke war led to some in mixed marriages being obliged to divorce and return to their parents, reinforcing Wlé and Ifá's arguments. mb says, 'It was a terrible situation'. Ifá strongly believes that conflicts also arise from economic, politics, and religion related circumstances, and can escalate quickly. He relates economic conflicts to limited land and water resources, where family leaders have key roles to play to mediate to prevent their escalation.

Secondary sources suggest that the inability to meet the economic needs of a people had the potential to cause conflict, hence the PS often discourage greed (Peaceful-Societies, 2019). Like Ifá's claims on disputes over water and the economy, Grech-Madin et al. (2018) write about water diplomacy:

the maintenance of peace regarding the use of water at the local, intrastate and international levels, citing examples of conflicts in Kenya between 'farmers and pastoralists' and across different ethnic groups (ibid, p. 107).

Economic and resources related conflicts are becoming increasingly common in the middle-belt, western and southern parts of Nigeria. Ekpenyong's work corroborates Wlé and Ifá's argument on the causes of violence in southern Nigeria as disputes over land ownership, resource control, politics and social institutions like chieftaincy and power struggles (2011). Other causes of conflict Ekpenyong mentions are jealousy, corruption, environmental destruction, discrimination, and religious rivalry (2011). Jealousy is commonly refuted among the PS.

Religion embedded in politics are other types of conflicts identified among the Yorùbá. Although religious violence is not very common, religious tensions have been reported: the Spetrí conflict and the Islamic hijab controversies in Osun and Kwara states are examples. The Yorùbá women and girls ordinarily wear traditional Yorùbá headgear and neck scarves at important occasions. Thus, the author describes the hijab tension as institutionally motivated, as headgears of various styles and colours were not a cause of conflict until recently when the hijab was presented as an Islamic symbol to be enforced in non-Muslim institutions like Christians' schools. Nigerians do not seem to question Muslim women use of the hijab in worship, homes, or marketplaces. The Osun and Kwara States hijab conflicts are thus traceable to their governments' enforcement on Christian communities' established schools. 
Disputes over the use of the hijab that led to violence at the Hijab Ejigbo Baptist High School [EBHS] (Makinde, 2014), and tension at the Baptist Secondary School Surulere Ilorin, (Edward, 2021) among others attracted much attention. The author was permitted to interview some teachers at the EBHS on the condition of anonymity because the case had been taken to court and the EBHS won, retaining its Christian ethos and hijab not allowed in the school. It was reported that after the government's imposition of the Islamic hijab on high schools in Osun State, the EBHS prevented Muslim girls from wearing the hijab at school, due to it being a Christian established school. Some Ejigbo Muslims took the law into their own hands, invading the school principal's office and assaulting him as reported in the interview (AB; CD). It took the intervention of the Ògiyán, the King of Ejigbo, who is also a Christian, to rescue the principal from the school and take him to the palace for his safety. Although the case was settled in court, the sustenance of the peace and living up to the school's ethos (with the initial school uniform) required the support of the parents, including the Muslims. The restoration of peace in Ejigbo shows understanding from both sides as they understood the problem, not being the clothing as both groups accept head covering of various types but the symbol it represents in their religious establishment. AB suggests:

When the government took over many (mission) schools in Nigeria, it was well understood that the culture of each school would be maintained by each school, but they began to impose the idea of hijab on our school, which we do not agree with.

This is the view of an insider and a witness of the hijab crisis in Ejigbo in Osun State. Another teacher colleague, CD adds:

The emergence of the hijab crises at the schools in Osun State was politically motivated as the government took over the schools and stopped their known ethos: prayers, uniforms, and other standards the schools were known for.

After the recent crisis at the EBHS and the subsequent court verdict, the parents agreed to take responsibility for any act of vandalism or violence perpetrated in the school by their children and wards.

The systematic taking over of Christian established and led primary and high schools in the west and south of Nigeria is becoming a concern to the southwest Nigeria Christians, due to the division created between the people by such intrusions. Thus, Inter-religious conflict is present even though uncommon. The alleged unhelpful role of some political elites like the Osun state politicians during the reign of Governor Rauf Aregbesola (Makinde, 2014), in the hijab crisis suggests leaders are responsible for the peace and/or conflict in their communities.

Similarly, the inability to circumnavigate the differences in culture has caused disunity and strain. Ifá (FGD3) suggests that inability to adapt to the changes in religions and cultural dynamics have the potential to cause disunity such as the Oro (IAR) indigenous festival prohibiting women's movement at night and sometimes during the day in modern times. The conflict between Muslims and the indigenous (IAR) worshippers likewise appeared in yo in the survey, Iwo interview, and between Christians and the Oro indigenous practitioners in Ògbómoso at some point in their history as suggested in the first focus group discussion FGD1 and by Anike (FI). mb mentions an example of an inter-religious conflict between the Nurudeen Islamic group and the Egungun festival in Ila-Orangun, which was later resolved.

Community structures have been used to resolve many conflicts. Also, the constructive use of language is noted as instrumental for conflict resolution, and peace maintenance through an understanding of one another's values and tolerance among the Yorùbá. Thus, misinformation, misinterpretation, and misrepresentation of other peoples' ideas or values should be avoided, while tolerance encouraged in a community that seeks peace or want to maintain their peacefulness. The communities that can handle information, and understand their neighbours recover from conflicts more easily as suggested in this study.

Considering secondary sources to support this finding, it has been suggested that the colonial role had destabilizing effects on Nigerians, especially on their leadership structures, which affects badly the southern Nigerians (the Yorùbá inclusive), and Christians in general (Idoko \& Addi, 2020; Turaki, 2000). Such de- 
stabilizing not only affect the Christian south but also the flow of authority among the southern monarchs (Oba), the head chiefs (baál) and the populace as the contemporary politicians exercise authority over the local kings and community leaders. While the Western-educated Yorùbá have tried to salvage it, Vaughan argues that the contemporary corrupt governance structure still holds on to the people (2006). Martineau equally proposes a re-visit of the positive roles of the kings (Oba) within African societies (2006). Ekpenyong provides solutions to conflict in general, like dialogue, forgiveness, promotion of social justice, workshops and spiritual engagement like prayer and evangelism, (2011), where the church should provide a leading role. Programme for Christian Muslim relations also do a lot in this direction (Procmura-Witness n.d.). Scholars have already identified the avoidance of jealousy and greed as areas of strength identified among the PS.

In short, land disputes and bad leadership have caused Nigerians untold hardship through the religio-political violence common during election campaigns (Lyons \& Reinermann, 2003), corruption and the hijab crises. The responsible leaders' role in managing these problems, where they are capable, can be productive. The narratives in this study show that the Yorùbá are not free of violence or disputes, be it physical, political, psychological, or structural, but attention on the Yorùbá's capacity to de-escalate conflicts and retain their peace must be given consideration as a contribution to peace research.

\section{B. Culture of Tolerance, Values and Understanding}

In the cumulative hierarchy chart show above, the Yorùbá culture, social interactions, community life, family and religion arise as particularly relevant to the way the Yorùbá maintain harmony among their people. The features that appear in support of the Yorùbá culture in this study are tolerance, understanding, and respect; stories and Yorùbá sayings; effective and good communication; brotherhood; financial support for one another; and good interpersonal relations. These features are found to be helpful in supporting the Yorùbá to retain their peacefulness when given attention.

According to Giddens:

Culture consists of the values the members of a given group hold, the norms they follow, and the material goods they create. Values are abstract ideas, while norms are definite principles or rules which people are expected to observe. Norms present the 'dos' and 'donts' of social life' (1989, p. $31)$.

Culture is used variously to capture size and nature of the society; according to Altman and Chemers, culture represents:

[... the] behaviors of a group or society. [...] indicate that cognitions, feelings, and behaviors are shared among a group of people in a consensual way. [...] these shared beliefs, values, and styles of behavior are passed on to others, especially children, and that the socialization and education of new members of the culture help pre-serve consensus from one generation to the next. (1984, p. 3)

Sewell Jr. describes culture in the context of 'learned behavior which include myths and customs, (2005, p. 80). Going by Giddens' definition and reference to others, the values, norms-rules, and social life described as the culture here have something to do with the way in which the Yorùbá respond to crises. While these could be applicable to any other human society, the crucial thing is the content of these norms and what the social life looks like, which often differs in detail from one culture to another. Giddens further writes:

[...] A culture has to be studied in terms of its own meanings and values - a key presupposition of sociology. [...] Since human cultures vary so widely, it is not surprising that people coming from one culture frequently find it difficult to sympathize with the ideas or behaviour of those 
from a different culture [...] In sociology, we have to ensure that we remove our own cultural blinkers in order to see the ways of life of different peoples in an unbiased light. (1989, p. 39)

Two issues arise clearly: meanings and values and not imposing the researchers' culture onto the subject. The use of meaning as one of the goals the culture stands for complements Sewell Jr.'s description of culture. The meaning and values are to be found in the language and the day-to-day life of the subject which this study attempts to clarify. However, the issue of the imposition of a foreign researcher's culture does not apply here, as this author is a native and speaks the language of the research participants. In the areas of discussion where he is not a practitioner (Islam, for example), a relevant practitioner was invited to the group discussion and the interview.

The study of culture and tolerance has also been addressed by a group of academics and expressed below in the Senegalese context:

Three Senegalese professors explain to the UW-Madison group several reasons for the peaceful relations between the country's religions. First, there is the culture of teranga, or hospitality, a deeply engrained Senegalese value taught at home and in school, said Badara Sall [...] 'When you encounter a person who doesn't share your religious belief', added Khadidiatou Diallo [...] 'you don't see that person as an enemy, but as a brother who at least shares the same culture'. (Senegal-n.a., 2009)

To the Senegalese, teranga, (hospitality) is the key factor in mutual love and peace maintenance. There are also indications of the presence of a peaceful Shi'i Muslim group in Senegal, (Leichtman, 2009), utilizing the common Senegalese teranga virtue. To the Yorùbá, cultural and communal life expressed in the form of tolerance, respect, effective communication and brotherhood or family (bí) among the Yorùbá are relevant to their peacefulness. Similarly, financial support for family and neighbours have more social and economic relevance among the Yorùbá. Culture, therefore, is a key to the Yorùbá's peacefulness.

\section{Linguistic Heritage: Music, and Storytelling}

One of the features of the Yorùbá culture that facilitates peacefulness is their use of language. This common language has become a binding entity, even when they are away from their hometowns as p (FGD3) has suggested in this study. Regardless of a person's religion, Ope often feels happy seeing or hearing somebody speaking Yorùbá while she was away from home (Yorùbáland). Similarly, Yorùbá wisdom sayings and music are identified as features for de-escalating conflicts and maintaining peace. Writing on culture, Giddens suggests:

[... 'culture' as equivalent to the 'higher things of the mind' - art, literature, music and painting [...] Culture refers to the whole way of life of the members of a society. It includes how they dress, their marriage customs and family life, their patterns of work, religious ceremonies and leisure pursuits. $(1989$, p. 31)

The Yorùbá culture embraces all the areas that Giddens suggests. Yorùbá struggled for their literature to be published in their language despite the colonial regime's opposition, (Adetunji, 1999; Akinjogbin, 1996; Atanda, 1996). They later used music to combat social injustice, diffuse tension and uphold their cherished heritages. Blessing in one of the interviewees at a radio station in Ibadan suggests that certain music and songs express norms that support the unity of the Yorùbá people. Some of the artists are well respected for their social, moral, storytelling, funeral, and praise songs. These musicians include King Sunny Adé (Adegeye), Ebenezer Obey (Fabiyi),[2] Kayode Fashola (Fashola).[3] Orlando Owoh (Owomoyela).[4] Kayode Fashola and Ogundare Foyanmu on social and ethics while Fla Kuti concentrate on justice and politics, (Kuti; Olaniyan, 2001).[5] Fla Anikulapo Kuti is a well-known Yorùbá artist, a humanist and a musician who often 
confronts exploitation, injustice, and other forms of maladministration in politics and religion in Nigeria and across Africa and globally.

These musicians promote the Yorùbá worldview and social interaction with their popularity and messages that their music conveys to the public. The music helps the masses to retain aspects of the Yorùbá culture, including its worldview of peace, ethics, social life, and courage. Most of their songs are accepted amongst Christians and Muslims, and are played at social functions such as weddings, naming ceremonies, dedications of new houses, and birthday parties with social commentary and moral lessons.

Concerning the control and prevention of conflict, certain sayings help to defuse disputes and prevent its degeneration into violence. Wlé (FGD3) points out some which are utilized by the Yorùbá to preserve their peaceful relations. Wlé suggests, Yorùbá ní àròjinl ('the Yorùbá have used deep thoughts and foresight'). The àròjinl takes place before an action is taken according to Wolé: 'They think of where and how an activity $[\ldots]$ will end and they are conscious of their roles if it is a joint activity with somebody else. They ask, "Should I be involved in this?",

Wlé gives an example of an incident in Ibadan. At the end of Ramadan (the Muslims' annual fasting), two Christians (a man and a woman) approached Wlé on different occasions, complaining of the early morning Muslim calls to prayer at the mosque and asserting the need to stop the noise. They said it often woke them up and disturbed the woman's ill mother. In his response, Wlé wished her mother a quick recovery and then argued that he (Wlé) gives the Islamic call to prayer without the use of loudspeakers and the woman should remember that the Christians use loudspeakers during their Wednesday and Friday night prayers and noted that he had not complained. This became an eye-opener for the woman, who then had to consider tolerance and mutual understanding. Wle called the mosque leaders to inform them of the complaints and the need for both sides to keep the peace without fault-finding. This is an example of how the Yorùbá seek opportunities to resolve disputes amicably before it degenerates into conflict. Such incidence could have ended in violence if it occurred among intolerant group. This positive handling of provocation resembles the comments the author received during the interview with Odu (FI). It also illustrates Adé's example of the Yorùbá youth's protest at the Oyo State governor's office in Ibadan about the Fulani leading their cattle to eat up their farm produce rather than taking the law into their own hands, (Ade).

Wlé's narrative shows sincerity, understanding, and awareness and use of the complaint's procedures, the effects of good leadership and empathy. The dispute was resolved due to the respect the complainants had for Wlé and his status in the community as a kind Yorùbá Muslim leader. Wlé's ability to handle the complaint as a leader in their community, addressing the leaders of the mosque and the Christian group is gratifying. The incidence did not degenerate to reporting to the police, an illustration of an alternative dispute resolution (ADR) among the Yorùbá. Wlé adds that their landlords' association meets regularly to resolve disputes and discuss developmental projects. The landlords' association is akin to the community leaders' meeting buttressed by Odu and Adé; and the kind that ceased to function and contributed to the collapse of harmony in Spetrí town, (FGD2; Lakunle, FI).

Another example is that of effective communication. This is seen in the Yorùbá saying, pl lak, o labo ('an apology could be said in a feminine or a masculine way'), the idea shared in Day's narration (FGD3). This implies that one can apologise in a genuine feminine way or in a masculine arrogant and unacceptable way, which the aggrieved will not appreciate. The use of gender here reflects thick description, relevant to the Yorùbá worldview. Masculinity is represented as strong and dominating (in a positive way). Yet, apologies must be rendered in a soft manner (feminine like) to reflect meekness, honesty, and repentance. Day says the Yorùbá takes genuine apologies seriously.

In the interview with Adé, a radio station manager, he discusses the wisdom sayings which basically inform the Yorùbá's readiness to tackle problems before it escalates. These include omb lókè, àwn ni aad dee ('when an object is falling from the top or from the roof, the net should be set to collect it'). That is, when you have privileged information about an impending problem or danger, you must prepare to tackle it. This saying prompts the Yorùbá to get ready for any danger that they are warned of, such as a plan to cause violence 
or a fight. In support of this, the FGD1 emphasizes the role of culture and elders in settling disputes, with Taiwo (FGD1) citing community interventions with their leader's cooperation and the interception of some reported invaders to Ògbómoso.

Adé confirms that the Yorùbá seek to know their neighbours and describe them by their name, house, compound, and town. If in doubt, they will ask, $m$ ilé ibo ni? ('which house are you from?'). According to Adé, if you know the family name of a young person initiating a controversy, the youth will be careful of continuing in such troublemaking, unless they are drunk. The Yorùbá say, ni ti a mnya ati baba r, agara daa ('knowing both parents of a troublemaker before the deed renders them powerless'). The Yorùbá could be proactive in challenging troublemakers and supporting them to seek peace. Odu suggests that family connections and knowing people by name in each community help to curb violence and inappropriate behaviour.

According to $\mathrm{Odu}$, the Yorùbá use ifinisùn (reporting) and ibániwí (discipline) to keep their communities safe under the control of their responsible community leaders. Reporting to elders or a designated leader, a form of complaint's procedure, is followed by a rebuke or discipline by a body of elders. According to Odu:

Rebuke often means a verbal and facial expression of discontent with the persons' behaviours, while discipline may be physical, like being given a fine or jobs to do on the farm (the community and leaders' farms) without pay. Both rebuke and discipline must be followed by apologies from the offender to the offended and the community in general, because the offences against one often have negative effects on the community's good name.

Equally, Odu suggests the idea of mluabi as cherished among the Yorùbá. mluabi concerns the expected behaviour of a responsible Yorùbá person, regardless of gender, age, or social, religion or economic status. Even though the mluabi qualities are seldom written, they are transmitted through Yorùbá storytelling, such as the respect for elders, respect for human life, appropriate greetings, and honesty, promise-keeping, good financial responsibility, caring for children and the elderly, truthfulness, shamefulness of identifying with a thief, industriousness, and love for neighbours. These qualities are reflected in the primary school Yorùbá literary texts, Alawiye Apa Kinni titi de Apa Kfa (the Alawiye textbooks parts 1-6), by J. F. dunj and Akinola Lasekan, (Odunjo, 1949-56), which numerous Yorùbá pupils have used for many decades. The translation of this enriching literature into other languages could help to promote these ideals in the early childhood education and ethical development of other non-Yorùbá children, thereby making further contributions to peace culture and peace education in general, a great heritage!

On whether the Yorùbá express their feelings as they seek to maintain a harmonious community, Adé suggests that they have the right to express their feelings and do so often. He discusses scenarios in which some people protested at the Ògbómoso FM Parrot Radio Station and at the governor's office in Ibadan about the Fulani (Bororo sect) leading their cattle to eat from the Yorùbá people's farms. According to Adé, the elders took the initiative, following the report and the protests to curb the Bororo's invasion of the Ògbómoso farmlands. In a later telephone conversation with a resident of Ilorin (Emman), however, there was another report of a similar Bororo invasion of farmland, where the farmer was unable to challenge them for the fear of being attacked or killed. Non-settler Fulani,[6] herders have been accused of violent crimes against many local farmers in Nigeria. These violent Fulani are known to be different from the already settled Fulani who have been living among the Yorùbá for many decades.

In contrast, Saratu, a secondary ethnie in Ilorin (FGD3), contests the Yorùbá's harmonious ambition, declaring it is all timidity as she was cautioned for rebuking a woman who allegedly lost her child through carelessness. The FGD3 responded that the Yorùbá are not timid as much as Saratu suggested but are rather considerate and thoughtful (the mluabi and aláròjinl attributes), not to increase the sadness of the bereaved woman through a verbal attack. Similarly, the FGD1 suggest the elders have been co-operating for peacefulness in Ògbómoso and such leadership is essential for curbing violence and injustice in their communities. In general, they suggested they would consider taking up arms against others a last resort as implied by Wlé's use of [al]áròjinl (thoughtfulness). 
Does peacefulness mean non-response to physical assaults? The invasions of various farmlands by the Fulani and the killing of farm owners have plagued the regime of President Muhammadu Buhari in Nigeria during the fieldwork in 2016 till present, 2021 while going to the press. Wole Soyinka (a Nobel Laureate) disclosed the readiness of the Yorùbá Ogun state local hunters to defend their people in case of a future trespassing and attacks in their communities, should the police fail to help (Folasade-Koyi, 2018; Makinde \& Dada, 2018). Three years later, some Ogun State people became refugees in the neighbouring country, the Republic of Benin (Oludare, 2021). The southwest governors have launched a joint local security unit called Àmtekùn to support the policing to secure their people, (Johnson et al., 2020). Peacefulness among the Yorùbá does not mean defenselessness but may need to be more proactive.

The ability of the Yorùbá to resolve their conflicts and retain peace has to do with their understanding, values, and the linguistic heritage of their culture. Considering secondary sources on language in a sociological context, Giddens writes 'No one disputes that possession of language is one of the most distinctive of all human cultural attributes, shared by all cultures $(1989$, p. 40). The harmony observable among the Yorùbá in their day-to-day community interaction has to do with their understanding, values, and use of language in their culture, which also has a link with their tolerance of religious differences in their society. Similarly, the Yorùbá's understanding and the idea of family, with their expressions concerning bi (family) and $m$ iyá kanna (motherhood) are noted as features that help to de-escalate tension and conflicts, thereby affirming Akinjogbin's Ebi theory, (1966). However, this research takes the bi theory further by unlocking other linguistic features that have contributed immensely to the unity of the Yorùbá. Wenden's paper comes to mind:

View[ing] language, not as a neutral medium for the description of reality but as actively shaping and giving meaning to human experience. It argues that the linguistic factor is taken into account in the analysis of and prescription for problems deriving from social and ecological violence that challenge contemporary societies. To that end, it outlines the components of a linguistic framework that illustrates how language communicates ideologies, which shape group attitudes and justify social practices that sustain the use of such violence. (Wenden, n.d.)

Wenden bases the argument on the 'theories of critical linguistics', arguing that linguistic factors should be considered while handling problems associated with social and ecological violence. Also important is how 'language communicates ideologies', which in turn has a direct impact, positive or destructive on society. The roles that the sayings and cultural values play among the Yorùbá cannot be over-emphasized.

The findings here show how the positive use of language in day-to-day communication and in music has influenced the peace-sustaining culture of the Yorùbá over the years. To that Wenden writes:

Despite the multifaceted role language plays in promoting direct and indirect violence, activities that would develop the linguistic knowledge and critical language skills for understanding how discourse shapes individual and group beliefs and prompts social action are conspicuously absent from peace education. This article aims to address this absence. It will present a framework for promoting critical language awareness, discuss its relevance to the preparation of critically literate citizens and suggest ways of incorporating it into programmes and curricula that educate for peace, (Wenden, 2007).

Wenden provides a work that is relevant to this study, arguing for the inclusion of 'how discourse shapes individual and group beliefs and prompts social action' in peace education. The positive use of language to promote peace and de-escalate tension should be further explored in peace studies.

Types of Yorùbá sayings are not exhaustive. They are useful for understanding Yorùbá's thoughts, worldview regarding disputes, de-escalation, and how they sustain peace in their community. These restrain the Yorùbá's response to conflict, to maintain harmony and more potent when passed on to the younger generation through oral traditions and via the Yorùbá literature used in schools, the evening moonlight (or bedtime) stories (ààl), and the media. An example of how language is used to promote peace is found in the Yorùbá bi theory. 


\section{D. $b i$ as a Family Bond}

The idea of the family bond or $b i$ is used amongst Yorùbá in many ways, biologically as well as in a social context and sometimes with the aim to pacify them in a time of conflict. Akinjogbin (1966) put forward the $b i$ theory into academic debates, and the subject has been discussed widely by other scholars (Brandon, 1997; Ogunremi \& Adediran, 1998; Westermann et al., 1969, 2008, Sholagbade, n.d.). The clue behind bi is that the Yorùbá view themselves as a family, an idea which permeates their society with potential to eases tension in times of conflict. According to Lateef in the interview (FI):

There are hardly any families in Yorùbáland without mixed religions. My brother is a Christian. He has just completed his $\mathrm{PhD}$ and is now a pastor. We get on with each other very well. We do not quarrel because of our religious differences. I let him know my religion is mine and he has his.

Lateef's case is one of a biological connection, a Muslims scholar having a Christian brother with whom there are no threats of Islamic apostasy is a good example of Yorùbá religious freedom and tolerance. Iya Waisu is a Muslim wife from Christian parents, married to a Muslim husband, while Kúnlé and Láńre (FGD2), and $\mathrm{mb}(\mathrm{FI})$ are Christians from Muslim background families.

The situation differs in the northern part of Nigeria, where religious conversion is labelled 'apostasy' and could attract an informal, illegal death sentence. Illegal, as such violence against a convert is not officially approved by the federal (national) government. Similarly, according to the FGD3 and Lateef, differences in religion among the Yorùbá of the same parents do not lead to physical violence and there is no evidence of apostasy-related deaths among the Yorùbá. They claim to see themselves as bi or $m$ ìyá kanna. The idea of the family kept Lateef and his brother in harmony after his brother's conversion to Christianity. This is an incredible relationship when viewed from a global religious context. A higher education in religions has not been found to impair the peacefulness of a people rooted in peaceful cultural system from this study.

İyab (FI) in the interview [a university undergraduate] mentions the hospitality she received during her travel to another part of Yorùbáland (Oke Ogun) for her university admission examination.[7] Her host did not know her prior to her arrival yet she spent the night with the host like a family, enjoying free accommodation and feeding for the night.

Múfú (FGD3) took the bi discussion further by exploring the origin of the term. Múfú suggests $m$ iyá kanna (as presented by Sholagbade) has been in use before the advent of Islam and Christianity amongst the Yorùbá to domesticate religion. The three religions (the Yoruba indigenous religion inclusive) retain the concept as a potent uniting force for harmony and to resolve disputes. Múfú suggests a similar concept as $m$ bàbá kanna ni wá (we are children of the same father) - which he claims must have predated both Islam and Christianity. The concepts are used same many as bi in conflict resolution and for pacifying people in times of dispute.

\section{E. Evolution of Other Related Concepts}

Some everyday Yorùbá sayings contribute to the building of harmony and maintaining peace. The idea is used in many Yorùbá communities to pacify people in conflict and to bring an end to a dispute, reminding the aggrieved of their common parenthood and the need to resolve their conflicts as soon as possible. This household conflict de-escalation and management strategy is also effective among Yorùbá Christians and Muslims, as they interpret motherhood and fatherhood in connection with Adam and Eve in their teachings. They both adopt Eve as the mother in the Yorùbá bi theory. FGD3 in Ilorin town and FGD1 in Ògbómoso highlight this connection. When the Ilorin FGD3 refers to Eve as the mother in bí theory [for a thicker description], the author challenged them to explain how the idea of Eve as a primordial mother comes into their conflict resolution apparatus. The use of Eve by both Christian and Muslim Yorùbá is an adoption of the $b i$ concept into their religious milieu as it is both relevant and useful in reconciliation and peace talks.

The idea of family is not the only concept used in conflict resolution among the Yorùbá but are the main ones the Yorùbá academia employ in the debate. When taken literally, in a biological context, $m$ iyá kanna 
would be irrelevant where there is no biological mother connection, as in a polygynous family, the practice common among the Yorùbá. Yet, the community or household elders still seek concepts of relationships that can persuade parties involved in a conflict to resolve their differences. In that sense, if the parties involved in a conflict are of the same father but with different mothers, their shared fatherhood is affirmed to persuade them to resolve their conflicts ( $m$ bàbá kanna), in line with Múfú's suggestion. In a situation when parties to a conflict do not have the same parents but were raised in the same large house (compound), the peacemaker affirms the common household to dissuade them from violence. In a similar way, just as $m$ bàbá kanna (same father) is used in context, so Ebi (family ties) is used either biologically or primordially; $m$ ilé kanna for same house or compound; omo àdúgbò kanna, same area/community; and omo ilú kanna, same hometown; and omo Yorùbá kanna, for same language. Peacemakers seek a relevant connection to affirm to help people in disputes to regain their harmony.

\section{F. Childhood Education among Peaceful Societies}

How does family life look like among the peaceful societies? The answer to this question is found in their ability to pass on their cherished values and knowledge to the younger generation. Biesele and Howell's study among the !Kung hunter-gatherers identify older people (often illiterates) as sources of knowledge, values, and culture for younger people, (the grandchildren). The older people provide an informal leadership role as mentors, make economic contributions by providing the knowledge of the local flora and fauna, and various skills needed for adult life, (Biesele \& Howell, 2015). The Yorùbá also teach their young morals, prohibitions, family related skills like drumming, crafts, farming, oil production, petty trade, and weaving. The !Kung divert the attention of children to other activities whenever they are quarrelling to diffuse the situation, (Draper, 1975) just as many Yorùbá do.

Fry's study among the Zapotec communities in Oaxaca in Mexico substantiate the indispensable roles of adult in the upbringing of the young in a communal society. Fry writes:

The Zapotec children of San Andrés and La Paz imitate the behaviors of their elders, especially their parents. They increasingly engage in behavioral patterns that are accepted, expected, and/or rewarded by other community members. (1992, p. 632).

Fighting among adults, according to Fry, corresponds to the children's attitude to fighting. San Andrés children watch their adults fighting on various occasions and they as children and teenagers also fight, (Fry, 1992). On the contrary, fighting is not acceptable among the La Paz adults, hence their children also shun fighting with one another. Reflecting on La Paz, Fry writes:

If they should become involved in a physical confrontation, they are likely to separate of their own accord. Husbands in La Paz tend not to beat their wives. La Paz men treat women with greater respect and are not nearly as jealous or possessive as San Andrés men ... [o]n several other occasions, I heard La Paz parents telling children to cease play-fighting. (1992, p. 632).

The parents, therefore, play a major role in mentoring children for peacefulness among the people of La Paz while the San Andrés' cultivate fighting, (Fry, 1992). 'San Andrés children learn that fighting and playfighting are expected of them - that these activities are viewed as part of their nature' while contrary is the case in La Paz, (Ibid.). So, it is implied from Fry's study that early childhood education and role modelling by parents or a community mostly informally, play a role in the formative years of a child and their value formation or future attitude to peacefulness.

\section{Conclusion}

Certain aspects of human culture can and have been useful as reconciliatory means to foster love, unity, and peace. The Yorùbá, for instance, are rich in culture with features to support a harmonious living like the mluabi, unwritten expected human values. The bi (family) theory is also an example that have been 
expounded beyond the biological family to cover neighbours and humanity to foster harmony. Peacefulness can be sustained by several connected features and values taught informally within their community. How the Yorùbá would navigate obstructions in the face of any prolonged pressure or unnecessary provocation to retain their peacefulness are areas that can be further explore.

\section{References}

AB. ( $2^{\text {nd }}$ September 2016). Interview at the EBHS, Ejigbo [Interview].

Ade. (14th September 2016). Interview at the Second Radio station [Interview].

Adegeye, A. S. King Sunny Ade: The Merciful God. On Full Album. YouTube. < https://www.youtube . com/watch?v=e8iVKww_Jac >

Adetunji, L. A. (1999). The Glory of Yoruba Nation. Lagos: Lichfield Nigeria Limited.

Akinjogbin, I. A. (1966). The Oyo Empire in the $18^{\text {th }}$ Century - A Reassessment. Journal of the Historical Society of Nigeria, 3 (3), 449-460.

Akinjogbin, I. A. (1996). The Growth of Yoruba Studies in the Western Region of Nigeria 1955-1965. Ibadan University Press.

Altman, I., \& Chemers, M. M. (1984). Culture and Environment. Cambridge University Press. https://doi.org/https://books.google.co.uk/books?id=VW85AAAAIAAJ

Anike. (2016). FGD1: The focus group discussion 1, Ogbomoso, Oyo State.

Arnold, M. (1869). Culture and Anarchy. In J. Storey (Ed.), Cultural Theory and Popular Culture: A Reader (Third ed.). London: Smith, Elder \& Co.

Atanda, A. (1996). The Yoruba People: Their Origin, Culture and Civilization. In . O. látúnjí (Ed.), The Yoruba History, Culture \& Language. Ibadan University Press.

Bagby, P. (1953). Culture and the Causes of Culture. American Anthropologist, 55 (4), 535-554. https://doi.org/http://www.jstor.org/stable/663783

Bauman, Z. (1999). Theory, Culture 83 Society: Culture as Praxis. SAGE Publications Ltd. https://doi. org/doi: $10.4135 / 978144621843$

Biesele, M., \& Howell, N. (2015). "The Old People Give You Life": Aging Among !Kung Hunters-Gatherers . <http://cas.uab.edu/peacefulsocieties/wp-content/uploads/sites/6/2015/11/BieHow81.pdf >

Bolaji, M. H. A. (2013). Between Democracy and Federalism: Shari'ah in Northern Nigeria and the Paradox of Institutional Impetuses. Africa Today, 59 (4), 93-117. https://doi.org/10.2979/africatoday.59.4.93

Bonta, B. D. (1996). Conflict Resolution Among Peaceful Societies: The Culture of Peacefulness. Journal of Peace Research, 33 (4), 403-420.

Brandon, G. (1997). Santeria from Africa to the New World: The Dead Sell Memories. Indiana University Press.

Briggs, J. (1994). "Why Don't You Kill Your Baby Brother?" The Dynamics of Peace in Canadian Inuit Camps". Gregor (Ed.), The Anthropology of Peace and Nonviolence (pp. 155-181). Lynne Rienner Publishers Inc.

Briggs, J. L. (1970). Never in anger: portrait of an Eskimo family. Harvard University Press. 
CD, E. (2 $2^{\text {nd }}$ September 2016). Interview at the EBHS, Ejigbo [Interview].

Dayo. (2016). FGD3: The focus group discussion 3, Ilorin, Kwara State.

Draper, P. (1975). !Kung Women: Contrasts in Sexual Egalitarianism in Foraging and Sedentary Contexts. R. Reiter (Ed.). Toward an Anthropology of Women. 77-109. Monthly Review Press.

Edward, Odun. 20 February 2021. Hijab: Kwara Government Directs Temporary Closure of 10 Schools, The Guardian. https://guardian.ng/news/hijab-kwara-government-directs-temporary-closureof-10-schools/>

Ekpenyong, E. O. (2011). The Social and Political Roots of Conflict in Nigeria; the Role of the Church. American Journal of Social Issues and Humanities, 1 (2), 117-136.

Emman. (15th January 2018). Telephone interview, Herdsmen Attack on Farmers in Ilorin Area of Nigeria [Interview].

Endicott, K. L. (1981). The Conditions of Egalitarian Male-Female Relationships in Foraging Societies. Canberra Anthropology, 4 (2), 1-10.

Fabiyi, E. O. Fi Mi Lokan Bale Oluwa. <https://www.youtube.com/watch?v=ivq239JVEt8>

Fashola, K. Ranti Omo Eni ti Iwo Nse o. On <https://www.youtube.com/watch? $v=Z t a J j i W V s 9 c>$

Folasade-Koyi, A. (2018). Herdsmen Killings: Soyinka Blasts Buhari. The Sun: Voice of the Nation. https: //www.sunnewsonline.com/herdsmen-killings-soyinka-blasts-buhari/

Fry, D. (1992). "Respect for the Rights of Others is Peace': Learning Aggression Versus Nonaggression among the Zapotec,". American Anthropologist, 94 (September), 621-639.

Fry, D. P. (2007). Beyond war: the human potential for peace. Oxford.

Gardner, P. M. (2000). "Respect and Nonviolence among Recently Sedentary Paliyan Foragers.". Journal of the Royal Anthropological Institute, 6, 215-236.

Giddens, A. (1989). Sociology. Oxford: Polity Press.

Grech-Madin, C., Döring, S., Kim, K., \& Swain, A. (2018). Negotiating water across levels: A peace and conflict "Toolbox" for water diplomacy. Journal of Hydrology, 559, 100-109. https://doi.org/https://doi.org/10.1016/j.jhydrol.2018.02.008

Howell, S. (1989). "'To Be Angry Is Not To Be Human, But To Be Fearful Is': Chewong Concepts of Human Nature". R. Willis (Ed.), Anthropological Perspectives. Routledge. 45-59.

Idoko, S., \& Addi, T. S. (2020). Politics and the Church in Nigeria in Just Before 2030 pathways to Nigeria's Prosperity, Peace, Justice, Unity, Security, Freedom and Sustainable Development. Trans Africa Journal of Contemporary Research. International Journal of Sustainable Development., 1 (5).

Ifá. (2016). FGD3: The focus group discussion number 3 in Ilorin, Kwara State.

Iyabo. (2016). I nterview at the Wildlife and Fisheries Department of the Osun State University, Ejigbo Campus [Interview].

Johnson, D., Sessou, E., Badru, D., \& Abubakar, S. O., James. (2020). Ogun, Oyo, Ondo, Lagos, Osun Assemblies Pass Amotekun Bill. Vanguard. https://www.vanguardngr.com/2020/03/ogun-oyo-ondolagos-osun-assemblies-pass-amotekun-bill/

Kunle. (2016). FGD2 Focus Group Discussion two at Sepeteri.

Kuti, F. 'Zombie' and 'Shuffering and Shmilling' views. <https://www.youtube.com/watch?v= 00psvbX1YB0 $>,<$ https://www.youtube.com/watch?v=Y-5IlljO78 >, 
Kyrou, C. N. (2007). Peace Ecology: An Emerging Paradigm in Peace Studies. International Journal of Peace Studies, 12 (1), 73-92.

Lakunle. (2016). FGD2 The focus group discussion number 2, Sepeteri, Oyo State.

Lateef. (2016). Interview of an Imam who also had Western Education and a Christian brother [Interview].

Lateju, F. T. (2012). Religious Conflict and Peace Building Initiatives in a Multi-Religious Nigeria. In F. T. Lateju, N. Samwini, \& D. Ayegboyin (Eds.), Christian-Muslim Relations in West Africa. West African Association of Theological Institutions WAATI.

Leichtman, M. A. (2009). Revolution, Modernity and (Trans) National Shi'i Islam: Rethinking Religious Conversion in Senegal. Journal of Religion in Africa, 39 (3), 319-351.

Lutz, C. (1990). "Morality, Domination and Understandings of 'Justifiable Anger' among the Ifaluk.". J. Gergen (Ed.), Everyday Understanding: Social and Scientific Implications. Sage. 204-226.

Lyons, S., \& Reinermann, D. (2003). Nigeria Strategic Conflict Assessment Methodology, Key Findings and Lessons Learnt. www.jstor.org/stable/resrep02468

Láńre. (2016). FGD2 Focus Group Discussion two at Sepeteri.

Makinde, Femi. 12 February 2014. "Tinubu meets CAN over Osun schools' crisis." PUNCH. <http: //www.punchng.com/news/tinubu-meets-with-can-over-osun-schools-crisis/.>

Makinde, F., \& Dada, P. (2018). Herdsmen: Police, Afenifere Backs Soyinka on Use of Hunters. Punch Newspaper. https://punchng.com/herdsmen-police-afenifere-back-soyinka-on-use-of-hunters/

Martineau, J.-L. (2006). Yorùbá Nationalism and the Reshaping Of baship. In T. Falola \& A. Genova (Eds.), Yorùbá Identity and Power Politics. Boydell and Brewer. Vol. 22, 205-228.

Melke, M. (1972). The Government of Peaceful Societies. Peace Research, 4 (1), 1-4.

Melko, M. (1972). The Qualities of Peaceful Societies. Peace Research, 4 (1), 5-8.

Melko, M., Hord, J. K., \& Weigel, R. D. (1983). Peaceful Societies Revisited. Peace Research, 15 (3), 39-42.

Mufu. (2016). FGD3: The focus group discussion number 3 in Ilorin, Kwara State.

Munch, P. A. (1964). "Culture and Superculture in a Displaced Community: Tristan da Cunha". Ethnology, 3, 369-376.

Odu. (19th Sept 2016). Interview at a major king's palace [Interview].

Odunjo, J. F. Iwe Keji Alawiye Fun Awon Omode, ati Awon Agbalagba (16 ed., Vol. 2).

Odunjo, J. F. [1949- (56)]. Iwe Kinni Alawiye Fun Awon Omode, ati Awon Agbalagba (Revised edition, 1 ed 2 ed.).

Ogunremi, D., \& Adediran, B. (1998). Culture and Society in Yorubaland. Rex Charles Publication in Association with Connel Publications.

Olaniyan, T. (2001). The cosmopolitan nativist: Fela Anikulapo-Kuti and the antinomies of postcolonial modernity. Research in African Literatures, 32 (2), 76-89.

Oludare, Ishola. Herdsmen Crisis: Scores of Ogun Indigenes now Refugees in Benin Republic. Daily Post. 23 February 2021. https://dailypost.ng/2021/02/23/herdsmen-crisis-scores-of-ogun-indigenes-now-refugeesin-benin-republic/>

Omobo. (2016). Interview in Mixed/Interfaith Marriage Context [Interview].

Osaghae, E. E., \& Suberu, R. T. (2005). A History of Identities, Violence, and Stability in Nigeria. Centre for Research on Inequality, Humanity Security and Ethnicity, Crise Working Paper no. 6. 
Owomoyela, S. O. O. Orlando Owoh: Ese rere. <https://www .youtube.com/watch?v=jvFkS16YBE0>

Parrinder, E. (1959). Islam and West African Indigenous Religion. Numen, 6 (2), 130-141. https://doi. org/10.2307/3269310

Peaceful-Societies. (2019). Peaceful Societies. Department of Anthropology, The University of Alabama at Birmingham. https://cas.uab.edu/peacefulsocieties/

Peel, J. (2016). Christianity, Islam, and Orisa-Religion: Three Traditions in Comparison and Interaction. Jstor. (Retrieved from www.jstor.org/stable/10.1525/j.ctt1ffjng5)

PROCMURA-Witness. n.d. "Faithful Christian Witness \& Christian Constructive Engagement with Muslims for Peace and Peaceful Co-existence." Procmura: https://procmura-prica.org/en/.

Robarchek, C. A., \& Robarchek, C. J. (1998). "Reciprocities and Realities: World Views, Peacefulness, and Violence among Semai and Waorani". Aggressive Behaviour, 24, 123-133.

Saraswati, B. (1995). Prakrti - The Integral Vision (Vol. Primal Elements: The Oral Tradition Vol. 1). Indira Gandhi National Centre for the Arts.

Saratu. (2016). FGD3: Focus Group Discussion in Ilorin, Kwara State on Nigeria.

Schein, E. H. (2012). What is Culture? In Mary Godwyn \& J. H. Gittell (Eds.), Sociology of Organizations Structures and Relationships. Sage Publication Inc.

Senegal-n.a. (2009). Senegal: Conversation in a University', Regions and Themes: Africa. https:// insideislam.wisc.edu/regions-and-themes/africa/senegal-conversation-in-a-university/

Sewell Jr, W. H. (2005). The Concept(s) of Culture. G. M. Spiegel (Ed.), Practicing History: New Directions in Historical Writing After the Linguistic Turn. Routledge. https://doi.org/https://books.google.co.uk/books?id=jdphGynmCo8C

Sholagbade, A. (n.d.). Eebi Islam and Christianity: A Contribution of "Faith-based Groups" to Sociopolitical and Economic Development of Epe, South-West Nigeria. http://c.ymcdn.com/sites/www.istr. org/resource/resmgr/africaregional2014wp/abiola_sholagbade.pdf

Susman, W. (2012). Culture as History the Transformation of American Society in the Twentieth Century. Pantheon Books \& (Knopf Doubleday Publishing Group). https://doi.org/https://books.google.co.uk/books?id=T0UIwfeW3JoC

Thomas, E. M. (1989). The harmless people (Revised edition, second Vintage Books edition. ed.). Vintage Books.

Turaki, Y. (2000). Tainted Legacy: Islam, Colonialism and Slavery in Northern Nigeria. Isaac Publishing.

Ukiwo, U. (2003). Politics, Ethno-Religious Conflicts and Democratic Consolidation in Nigeria. Journal of Modern African Studies ,41 (1), 115-138.

Vaughan, O. (2006). Chieftaincy Structures, Communal Identity, and Decolonization in Yorùbáland. In T. Falola \& A. Genova (Eds.), Yorùbá Identity and Power Politics. Vol. 22, (pp. 177-191). Boydell and Brewer.

Wenden, A. L. (2007). Educating for a critically literate civil society: incorporating the linguistic perspective into peace education. Journal of Peace Education, 4 (2), 163-180. https://doi.org/10.1080/ 17400200701523561

Wenden, A. L. (n.d.). 'Achieving a Comprehensive Peace: The Linguistic Factor'. https://www. researchgate.net/publication/227956575_Achieving_a_Comprehensive_Peace_The_Linguistic_ Factor

Westermann, D., Smith, E. W., \& Forde, C. D. (1969, 2008). Africa. The University of California, 39. 
Williams, R. (2006). The Analysis of Culture. In J. Storey (Ed.), Cultural Theory and Popular Culture: A Reader (Third ed.). Pearson Prentice Hall. (Williams, R., 1961, The Long Revolution, London: Chatto \& Windus. 57-70.

Willis, R. (1989). "The Peace Puzzle in Ufipa." In S. H. a. R. Willis (Ed.), Anthropological Perspectives. Routledge.

Wlé. (2016). FGD3: The focus group discussion number 3 in Ilorin, Kwara State.

\section{Notes:}

[1] See <https://cas.uab.edu/peacefulsocieties/>, accessed 27/08/2019, updated 09/05/2020.

[2] Ebenezer Obey Fabiyi's songs are well patronized on the YouTube.

[3] Fashola's 'Ranti Omo Eni ti Iwo nse o' YouTube had about 533,000 views on 11/01/2020.

[4] Orlando Owoh's real name is Stephen Oladipupo Olaore Owomoyela.

[5] Fla Kuti's 'Zombie' uploaded to the YouTube 14 April 2011 accessed 11/01/2020 had 41,216 views while 'Shuffering and Shmilling' uploaded 5 Nov 2011 had over 1.85 million views.

[6] An ethnic group found in northern Nigeria and many other parts of West Africa.

[7] Oke Ogun in yo State of Nigeria experienced religious related violence but the community members seem to be humane in their relationship to resolve it. 